\title{
CONTEMPORARY PROSPECTS FOR THE RAILWAY ENGINEERING INDUSTRY IN UKRAINE IN THE VIEW OF ECONOMIC CRISIS
}

\author{
Artem BILOUS ${ }^{1}$, \\ Institute of International Relations of Taras Shevchenko National University of Kyiv, Ukraine
}

\begin{abstract}
The purpose of the paper is to explore the current state of the railway engineering industry in Ukraine, the prospects of its development, current threats and possibilities; to propose incentives for the railway industry development. Methodology. The research was based on open sources of statistical information which was compared by years in relation to events in political and economic spheres. Data was also received from producers' web-sites. Analytical economic articles have been also used to obtaine the full scope of information regarding the railway industry in Ukraine. Results of the research showed that today Ukraine had a grea demand for the rolling stock as the current rolling stock is obsolete and $98 \%$ of it reached their lifecycle end. Currently Ukraine has six car building plans and two plans for construction of locomotives and they offer a variety of units of the rolling stock. The main customer for all those plants is the State Railway Administration of Ukraine "Ukrzaliznytsya", that, for recent years, almost had not ordered new rolling stock. The problem is that Ukrzaliznytsya does not have own funds to pay for the rolling stock renewal, and credit funds are almost unachievable due to economic crisis and structural reorganization of the railway operator. That's why the plants went abroad with their products, and Russia became the main customer abroad. Due to the events of 2013-2015, Russia closed its market for Ukrainian rolling stock by non-issuance of technical certificates for the rolling stock. However, in the period of political and economic instability, together with the recent cancellation of import duties to the EU countries, Ukrainian rolling stock producers have now a real chance to diversify their customers and explore new markets. Practical implications. Thus, to overcome the current difficulties, Ukrainian government has to introduce a special program to renew the rolling stock, to encourage governmental-private enterprise, and the producers should explore new markets as they have products to offer in Europe and other regions. Value / originality. The received data show that the Ukrainian railway industry has perspectives in case of finding new markets for its products. The technical level of the produced rolling stock is on the high level and can be easily improved.
\end{abstract}

Key words: railway engineering industry, rolling stock, renewal, Ukrzaliznytsya, production, crisis, state regulation.

JEL Classification: E23, L62, M11, 018

\section{Introduction}

Analysis of the current state of the field of railway engineering in Ukraine gives grounds to say that, despite negative trends in the economy of Ukraine and the market of railway services, railway engineering in Ukraine is developing. The absence of a deliberate governmental strategy of procurement of new rolling stock has led to the fact that most businesses of engineering complex appeared in conditions of necessity of self-financing and independent search for new markets outside Ukraine. The result was a significant aging of rolling stock and loss of competitive positions compared to the railway companies of neighboring countries. The result was the partial stagnation of industry and outflow of qualified personnel, moral and physical aging of technologies and equipment.

Reorientation of national railway engineering to intensive, faster way of development involves the necessity to resolve a complex of problems, interconnected and interdependent in the legislative, regulatory, financial, economic, educational, personnel and other areas. That is what necessitates studying the state of machine-building of Ukraine and its governmental regulation.

\section{General view of railway industry}

Transport infrastructure occupies an important place among the factors of economic development in the past years and today. Transport delivers cargo and carries people, and the largest volumes of transportation by land transport are carried out by railway. At the time when the first railways appeared, towns sometimes came into conflict through which one the railway will pass because at that time a new mode of transport gave a significant boost to economic development. There were even cases where during the laying of the first transatlantic railway inhabitants of towns in the United States could even move

Corresponding author

${ }^{1}$ Department of International Business, Institute of International Relations of Taras Shevchenko National University of Kyiv.

E-mail: bilousartem@ukr.net 
their homes to railway. However, the railway was not only conducive to economic development, but also had great importance in the logistical chain of military campaigns, since it was the best way to quickly change the deployment of military equipment and personnel. To prevent this, spoils of the railroad tracks took place and the trains were blown up. However, the role of railways in peacetime far outstrips the notional damage during the hostilities.

In the world there is a situation when there is no single standard of width of railway track; track width from 600 to $1676 \mathrm{~mm}$ is used in the world. The most common of them are "standard" or "Stephenson" width of $1435 \mathrm{~mm}$ and "Russian" of $1520 \mathrm{~mm}$. The first is used almost all over Europe, the USA, China and other countries. The second one is in the former Soviet Union, Mongolia, Finland. Thus there is a situation when trains can not travel freely, for example, between Ukraine and Europe, this requires replacement of cars' boggies. This, in turn, does not promote economic cooperation of the CIS and EU countries.

Railway engineering sector in Ukraine appeared in the nineteenth century from construction of plants for the construction of locomotives and cars and repair workshops. Later, in Soviet times, new factories appeared for building cars and locomotives. Today in Ukraine there are six wagon building plants in Kremenchuk, Mariupol, Krivoy Rog, Stakhanov, Kharkiv (excluding carriage repair) and two plants for the production of locomotives in Luhansk and Dnipropetrovsk (without locomotive repairing). Production of EMU and DMU (electric multiple unit and diesel multiple unit) is carried out at two factories that are among these. In 2015, there is a planned construction of the plant for production of electric locomotives at Zaporozhye electo locomotives repairing plant. The project is to be implemented in partnership with Skoda Transportation (Czech Republic). The author considers it appropriate to review prospects of wagons and locomotives construction in Ukraine separately (Kindzerskyi Yu. V., Mykytenko V. V., Yakubovskyi M. M. and others, 2009).

\section{Car-building}

Construction of railway cars, namely freight cars, has the largest volume of production in Ukraine and export abroad. In 2013, due to reduced purchases by Russia, production decreased twice. According to experts, neither Ukrainian nor any other of the markets will be able to load the capacities of our plants. Everything leads to the fact that production figures this year will fall lower than at the crisis times of 2009, when only 13 thousand of cars were released. Meanwhile, prospects in key market continued to narrow. With a view to the economic integration, the countries of the Customs Union in August 2014 transferred to rail safety evaluation of products, including freight cars, according to the requirements of technical regulations. Today, the industry in Russia seriously at odds with Ukrainian standards in assessing safety. New standards for Ukrainian factories will have more serious negative factor in the Russian market than single limits of Rostransnadzor.
Theoretically, the supply of cars for the domestic market could help Ukrainian car-producers survive. According to analysts of CTS-Consulting, annually in the period 2014-2020 7,9-10,5 thousand of cars will be charged, $70 \%$ of which is park of "Ukrzaliznytsya". However, the state monopoly does not have money for rolling stock renewing. Within 2010-2014 just 2.1 thousand of freight cars were purchased, this year it is planned to buy another 1.5 thousand.

In mid-March 2014, Minister of Infrastructure of Ukraine said that the purchase of railway rolling stock preference will be given to domestic producers and considered all possible financing schemes, leasing, credit offers, including credit lines of the EBRD. Much will depend on how much money and on which schemes will be attracted by "Ukrzaliznytsya" during upgrades.

Private Ukrainian companies buy cars in small quantities. For example, thelargest private freight transportation company "Lemtrans", in 2014, bought 645 cars of domestic production, this year it plans to buy another 3 thousand. According to the company "Lemtrans" representatives, domestic producers offer the best combination of price, quality and delivery terms, as the company is cooperating with Ukrainian enterprises. The company"Ferrexpo", which owns Poltava GOK, last year, bought in Stakhanov Railcar Plant 267 cars, this year there are plans to supply another 300 units.

The need for Ukraine in the new grain cars is 6.7 thousand units. But a severe shortage of this type of cars has not yet led to a boom in its production. Purchase of such a number of grain cars, according to the State Food and Grain Corporation of Ukraine (DPZKU) required an investment of 600 million US dollars, and farmers do not have the money. This leads to the fact that last year DPZKU seriously wondered about the purchase of 2 thousand of Chinese grain cars on the Chinese loan.

The main market for domestic cars has traditionally been in Russia, which imported about $85 \%$ of Ukrainian production. However, the last two years Russia reduces purchases of Ukrainian cars. In 2013, the production of cars in Ukraine dropped by half - to 23.8 thousand. Units, and as reduced exports to Russia up to 14 thousand units. The reduction of exports is primarily due to the surplus of rolling stock in Russia, which is about 120-130 thousand units (around 10\% rolling stock). The important fact was that Russia suspended the certificates of Ukrainian carbuilding enterprises in late September-October 2013.

Among Russian and Ukrainian markets, our carproducers still can count on delivery of their products to the markets of "Space 1520", where there is the similar train track width. Primarily, these are Kazakhstan, Belarus and the Baltic States. But for all machine builders, there is not enough volume of market. Since Kazakhstan and Belarus are part of the Customs Union, the delivery of our cars to these countries may be limited after Russia, in the case of usage by the latter some restrictions. According to experts, about 2-3 thousand of cars can be sold to the Baltic States, which are also located in the "Space 1520". However, 
last year the supply of Ukrainian cars in that region also declined. During 10 months of 2013, only 1.13 thousand of cars were sent for export that is twice lower than in 2012. Supply of cars to Central Asia also decreased. Export supplies last year to these countries were 3.6 thousand units, which is $60 \%$ less than in 2012 . In addition, the structure of production has changed: the rate of gondola fell for tanks. According to experts, domestic car producers can send a total of about 5 thousand cars a year to counries of "Space 1520" (except Russia).

To make a break-through to the EU market, there are some obstacles for Ukrainian car producers. Firstly, Ukraine produces cars for the railways with a width of $1520 \mathrm{~mm}$, while the European countries (except the Baltic states) adopted a different standard. Secondly, the European market in its capacity is several times lower than the Russian, as the share of railway transport in cargo transportation is only $20 \%$. Thirdly, in the next five years, analysts predict a drop in sales of new freight cars in Europe. In Europe and the US, consumers choose cars with the largest capacity that may be associated with the load on the axle, number of axles, the cost of repair and overhaul mileage, convenience and speed of unloading of a car, car's versatility under various loads.

Last year the head of the supervisory board Kryukov Car Works (KVSZ) said that for the transition to European standards the company needs about $150 \mathrm{mln}$ euro of which more than 40 million should be spent on implementing the European environmental standards and more than 100 million for the purchase of new equipment and development of new products. He also said that the plant has no such resources, and without that the company would not be able to break through the EU. However, the regulatory framework for the supply of products to the European market, the company has. KVSZ has European quality certificate ISO, American AAA certificate and certificate for the right to teach employees the requirements of IRIS - International Railway Industry Standard. Stakhanov Railcar Plant also is considering certification for compliance with IRIS, since the presence of such a certificate is a prerequisite for entering the European market.

In the current situation, car producers pay attention even to distant markets. For example, in 2012 KVSZ agreed with Kenya to supply about 1 thousand of cars of different types, accessories and spare parts for rolling stock worth about 60 $\mathrm{mln}$ USD. It was planned that in Kenya there will be equipment and final cleaning of cars established. Agreement on the supply of Ukrainian cars to Kenya amounted to $7 \%$ of annual income of KVSZ. This company has provided significant discounts to Kenyans to enter this new market. Markets in countries such as Kenya, where there is an established domestic production of cars, are promising for Ukrainian car producers, as products of Ukrainian companies are much cheaper than from the British and Japanese companies, where the cost of cars is about $30 \%$ higher.

One should consider passenger car building in Ukraine separately. It is presented by three plants in Kremenchug,
Luhansk and Kharkiv, the first two of which build cars in full cycle, and the latter makes the overhaul with the prolongation of cars. The leader of the industry is Kryukov Cars Works, which produces cars of distant following, interregional cars and high-speed trains. To date, the plant built and delivered to customers more than 500 units of passenger rolling stock since 2002. The largest number of cars was delivered to UZ, although the last 3 years there was hardly buying of cars by national carrier. In this connection, the manufacturer switched to a more active development of foreign markets. Today these are Belarus (a joint venture with Gomel Car Plant), Kazakhstan, Tajikistan. The plant has mastered the production and received permission of inter-sectoral commission to produce passenger cars of dimension RIC (Regolamento Internazionale delle Carrozze - an international agreement with the requirements for railway rolling stock that can be used on the railways of countries participating in the agreement; this includes all European states), which is less than the accepted clearance for "Space 1520". Thus, the company discovered the way to the European market, which can eased by the abolition of restrictions on the import of Ukrainian goods to the EU. As for the Russian market, the situation is complicated by the existence of a strong competitor such as JSC "Tver Car Works," which produces a similar range of products of passenger car building as the does KVSZ.

Recently, there was almost no upgrade of motor-wagon rolling stock (EMU and DMU). Speaking of suburban trains (excluding purchase of 10 trains Hyundai Rotem), the latter train was acquired in 2008, and in 2013 one DMU was purchased (domestic production). Overall, 50 EMU trains were delivered to Ukrainian Railways, with the oldest of those currently on the balance, maintained since the beginning of the 60es of XX century. All domestic electric and diesel trains were manufactured at the plant "Luhansktplovoz." It should be noted that their technological level, unfortunately, is far from corresponding to the current level. The plant itself is more focused on production of diesel locomotives and electric locomotives, that's why the production of commuter trains there in the near future is not going to renew. But soon, in stabilizing the political and economic situation in Ukraine, KVSZ intends to present their vision of suburban electric train made on a modern technological level.

\section{Locomotive-building}

The park of UZ locomotives consists of diesel locomotives (passenger, freight and shunting) and electric locomotives (passenger and cargo; $3 \mathrm{kV} \mathrm{DC}$ and $25 \mathrm{kV}$ AC current, dual-system - designed for both currents). Today in Ukraine there are two factories that can produce locomotives: Dnepropetrovsk electric locomotives building plant (DEVZ) and Luganskteplovoz, which actually deals with the production at present time. It produceы all kinds of diesel locomotives and freight electric DC and AC locomotives. The latter are of Russian 
electric series $2 \mathrm{ES} 4 \mathrm{~K}$ and $2 \mathrm{ES} 5 \mathrm{~K}$ that actually, changing some nodes are Ukrainian electric locomotives series 2EL4 and 2EL5 respectively. The plant itself is owned by the Russian "Transmashholding", and so depends on UkraineRussia relations. That is, given the events of early 2014, Ukraine can not fully plan to replenish its own locomotive fleet by Lugansk locomotives. An alternative could be Dnepropetrovsk electric locomotives building plant that already in the independent Ukraine produced 40 electric freight DC locomotives and 18 passenger AC locomotives. In general, these amounts are meager renovation of rolling stock, moreover, most locomotives had some design flaws that, to some extent, prevented the further release.

In 2013, an agreement was signed to establish a joint enterprise on the basis of Zaporizhzhya electric locomotives repairing plant (ZERZ) with the company Skoda Transportation. The project involves the construction of new premises for the full release of electric locomotives by the following structure: 50 passenger dual-system, 330 singlesystem passengers, 100 dual-system freight locomotives. With the procurement of freight single-system locomotives from Luganskteplovoz, this should provide Ukraine with a new generation of electric locomotives.

With diesel locomotives, the situation is the opposite. When there is a possibility in Ukraine to produce all types of diesel locomotives (Luganskteplovoz), there is no need for them now in Ukraine. This is related to electrification of particularly loaded areas (released locomotives) and with rising prices for fuel and lubricants, which increase the cost of transportation by diesel locomotives. Today, all diesel locomotives that are produced in Ukraine (cargo only) are exported, priorly to the Russian Federation, OJSC "Russian Railways", which has a monopoly of rail transportation and is state-controlled. Unfortunately, the production of locomotives in recent years is hardly updated, and in case of strengthening economic war between Russia and Ukraine, documentation for locomotives can be exported to Russia for the organization of production on its territory. It should be added that during the last 20 years 4 passenger diesel locomotives and a shunting one of own development were released for UZ. The promising areas of "Luganskteplovoz" are the following:

- replacement of old main locomotives on non-electrified areas;

- replacement of obsolete two-piece series 2M62 diesel locomotives used on Lviv and South-West railways in passenger traffic with modern diesel locomotives TEP150; - production of main cargo electric locomotives;
- production of shunting locomotives series TEM103 used to replace current shunting locomotives;

- adapting diesel locomotive TEP150 to the requirements of other countries, including EU member states, with a view to export (locomotive corresponds to the "euro clearance");

- improving existing DMU DEL02 and arrangement of its supplies to Ukrzaliznytsia and other countries.

Regarding DEVZ, the production main electric locomotives is not planned there it in the near future. In fact, the plant returned to what from it began, to the production of industrial quarry and mine electric locomotives. DEVZ has the potential to enter the new markets of the Middle East, Asia and Africa. Equipment, operating in developed countries such as the EU or the US, is under higher pressure of strict requirements than those that the manufacturer can perform even soon. Of course, the Russian market is available for the plant, but the risks are the same as for other companies - organization of production of machinery in Russia and the rejection of Ukrainian counterparts.

\section{Conclusions}

Thus, having considered the present state of sphere of railway engineering in Ukraine, the following conclusions can be reached.

1. The technological level of railway transport of Ukrainian production is acceptable but needs updating to modern technical standards and market requirements.

2. The basis for the support and development of national railway engineering should be a state program for rolling stock reneval that should not be declarative, but real. Also the author considers it necessary to legislatively regulate the participation of private carriers with their own rolling stock, which could at their own expense buy rolling stock, preferring the most appropriate offers. It should stimulate domestic producers to increase the competitiveness of their products. Also the author draws attention to the need to implement public-private partnership in the production of rolling stock.

3. Producers should independently seek new markets except Russia. The signing of the economic part of the Association Agreement with the EU should facilitate the access of producers to the European market. One should focus on the countries of the former Warsaw Pact (the Soviet Union has supplied rolling stock there of own production) and not very wealthy EU countries such as Serbia, Croatia, Greece and others.

\section{References}

Carriage of RIC clearance is an adequate addition to production listof passenger cars of KVSZ. - Web Source. http:/\%ww.kvsz.com/index.php?option=com content\&view=article\&id=562\%3A-ric-\&catid=1\%3Ae\&Itemid= $105 \&$ lang $=\mathrm{ru}$

Czech company Skoda Transportation purchased share in Zaporozye enterprise. - Web Source. http://day.zp.ua/news/37887.html

Kindzerskyi, Yu. V., Mykytenko, V. V., Yakubovskyi, M. M. and others. (2009). Potential of national industry: goals and mechanisms of effective development. Edited by Kinzerskyi Yu. V. Kyiv: NAN Ukrainy; In-t ekonom. and prognostication. 
Kriukov car-building plant keeps on production reducing. - Web Source. http://delo.ua/business/krjukovskijvagonzavod-prodolzhaet-sokraschat-proizvodstvo-232691/

Kuzmin, O.Ye., Kniaz, S.V., Hnylianska, L.Y., Zinkevych, D.K. (2010). Innovative programs of machine-building enterprises: creative solutions and models of their transferting. Lviv: SPOLOM.

KVSZ may provide Kenia with discount for carriages. - Web Source. http://www.kremenchug.ua/news/ business/17136-kvsz-mozhet-predostavit-kenii-skidki-na-vagony.html

KVSZ produced and provided to customers 500 units of passengerrollingstock.-Web Source.http://www.kvsz.com/ index.php?option=com_content\&view=article\&id=585\%3A----500--- \&catid=1\%3Ae\&Itemid=105\&lang=ru

KVSZ was the first in Ukraine to work under conditions of IRIS standard. - Web Source. http://www.kvsz.com/ index.php?option=com_content\&view=article\&id=597\%3A-iris\&catid=1\%3Ae\&Itemid=105\&lang=ru

List of car-building plants. Web Source: http://made.in.ua/index.php?cat=60\&subcat=728

Malashchuk, D.V. (2005). The competitiveness of Ukrainian machine-building complex in case of globalization of international markets: Author's thesis for PhD grade: 08.05.01 „World economy and international economic relations". Kyiv: Ukr. akad. zovnish. torhivli.

Need in renewal of park for passenger transportation is 500 cars annually. - Web Source. http:/ /www.magistral-uz.com.ua/ news/potreba-v-onovlenni-parku-dlja-pasazhirskih-perevezen---500-vagoniv-worichno.html

Tarasova, N.V., Kalinichenko, I.S., Romanesko, V.A. and others. (2007). Machine-building in Ukraine: trends, problems, perspectives. Nizhyn: TOV "Vydavnytstvo "Aspekt-Polihraf".

Ukrainian car producers reduced export to Russia by $40 \%$, but increased the supplies of special cars. «Azovskiy mashynostroitel» \#3, 1.02.2014. - Web Source. http://www.azovmash.info/print.php?id_new=5083\&id_num=460 Ukrainian cars come back to markets. - Web Source. http://poslezavtra.com.ua/ukrainskie-vagony-vozvrashhayutrynki/

\section{Артем БИлОус}

\section{СОВРЕМЕННЫЕ ПЕРСПЕКТИВЫ ОТРАСЛИ ЖЕЛЕЗНОДОРОЖНОГО МАШИНОСТРОЕНИЯ В УКРАИНЕ В УСЛОВИЯХ ЭКОНОМИЧЕСКОГО КРИЗИСА}

Аннотация. Целью работы является исследовать современное состояние отрасли железнодорожного машиностроения в Украине, перспективы его развития, текущие угрозы и возможности; предложить пути развития отрасли железнодорожного машиностроения. Методика. Исследование основано на статистической информации из открытых источников, которая сравнивается по годам в привязке к событиям в политической и экономической сферах. Данные также были получены с веб-сайтов производителей. Также, при исследовании вопроса использовались аналитические экономические статьи по вопросам развития отрасли железнодорожного машиностроения в Украине. Результаты исследования показали, что сегодня в Украине существует огромный спрос на подвижной состав, так как $98 \%$ ныне эксплуатируемого приблизились к граничному сроку своей эксплуатации. На сегодняшний день в Украине имеется шесть заводов по производству вагонов и два по производству локомотивов. Основным заказчиком всех заводов является Государственная администрация железнодорожного транспорта Украины «Укрзализныця», которая в течение последних нескольких лет практически не обновляла подвижной состав. Проблема заключается в том, что у Укрзализныци нет своих средств на покупку подвижного состава, а кредитные средства по большей части недоступны из-за экономического кризиса в стране и структурных преобразований, которые сейчас происходят на Укрзализныце. Поэтому заводы вышли на внешние рынки, а Россия стала основным заграничным потребителем. Из-за событий, имевших место в Украине в период 2013-2015 гг., Россия закрыла внутренний рынок для подвижного состава из Украины путем отказа в продлении сертификатов на поставку продукции. В то же время, в период политической и экономическо нестабильности, в то время, когда упрощается выход на европейский рынок, украинские производители получили реальный шанс диверсифицировать рынки сбыта. Практическое значение. Для того, чтобы преодолеть текущие сложности, правительство Украины должно внедрить специальную программу по обновлению подвижного состава, поощрять государственно-частное партнерство, а производители должны осваивать новые рынки, поскольку у них есть продукция, которую можно предложить в Европе и других странах. Поскольку в Европе используются другие железнодорожные стандарты, производители должны адаптировать под них свою продукцию. В то же время, на украинских предприятиях уже готовы образцы продукции, соответствующей европейским требованиям. Значение/оригинальность. Полученные данные показывают, что украинская отрасль железнодорожного машиностроения имеет перспективы в случае нахождения новых рынков для своей продукции. Среди таких рынков могут быть как страны с аналогичными стандартами железных дорог, так и страны с отличающимися стандартами. Технический уровень выпускаемого украинскими предприятиями подвижного состава находится на высоком уровне, хотя и может быть легко повышен. 